\title{
ANIMASI 2D “BULLYING” SEBAGAI MEDIA MENANAMKAN NILAI- NILAI PANCASILA PADA ANAK SEKOLAH DASAR
}

\author{
Arif Agung Swasono ${ }^{1}$, Andi Haryanto ${ }^{2}$, Novi Mayasari ${ }^{3}$ \\ ${ }^{123}$ Dosen Program Studi Desain Komunikasi Visual \\ Fakultas Seni Rupa ISI Yogyakarta \\ 1ariefagungsuwasono@gmail.com, ${ }^{2}$ vasciola.hepatica@gmail.com, ${ }^{3}$ novi_cokromiharjo@yahoo.com
}

\begin{abstract}
D animated film with the title of "bullying" was intended as a medium to instill the values of Pancasila to elementary school children. With 2-dimensional film, children are expected to be easier to understand the values of Pancasila because basically at that age, children will be easier to capture the visual information. In addition to the 6-12 year old children are more likely to imitate things that are considered attractive by them. It can be seen from the influence of the film Upin Ipin, in the minds of the children of Indonesia. Moreover, it is still very rare animated films in Indonesia, especially those charged values of Pancasila, even rare animated films is precisely contrary to the values of Pancasila.

The process of designing 2D animation movie "bullying" encompasses the manufacturing phase of the synopsis, script (script) and the story board, character design and background design of animated films. Then proceed to the stage of visualization of the animated film that includes key animation process, In between and background as well as post-production process that includes dubbing, compose final, noise design and mastering. The method used in creating this animated film is a method of $5 \mathrm{~W}+1 \mathrm{H}$ Analysis. $5 \mathrm{~W}+1 \mathrm{H}$ is an overview of What, Why, Where, Who, when, and How. Benefits of this study was to design a media that can be used to embed the principles of Pancasila for children as the next generation in a way that is attractive and easy to accept.
\end{abstract}

Keywords: Film, Animation, Pancasila, $2 D$

\section{PENDAHULUAN}

Nilai-nilai Pancasila merupakan filsafat (pandangan hidup) bangsa Indonesia, sehingga menjadi jati diri bangsa yang diyakini sebagai sumber nilai atas kebenaran, kebaikan, keadilan dan kebijaksanaan dalam hidup bermasyarakat, berbangsa dan bernegara. Sebagai dasar filsafat negara sudah seharusnyalah kita sebagai bangsa Indonesia melestarikan dan memegang teguh nilai-nilai Pancasila. Sebagai bangsa penganut Pancasila, bangsa Indonesia harus selalu memegang teguh nilai-nilai Pancasila dalam setiap aspek kehidupannya. Bahkan bisa diibaratkan bahwa bangsa Indonesia bernafas dengan Pancasila, namun sayangnya akhir-akhir ini kemorosotan nilai-nilai Pancasila telah semakin menjadi-jadi. Maraknya kasus korupsi di negara ini juga dapat menjadi bukti merosotnya nilai-nilai Pancasila sebagai dasar filsafat negara. Kemerosotan nilai-nilai Pancasila juga terjadi pada para generasi muda kita. Kita bisa melihat bahwa budaya kekerasan telah merembes pada generasi 
muda, dimana kasus-kasus tersebut terjadi dengan alasan yang sangat sederhana seperti putus cinta dan aktualisasi diri. Selain itu kita juga bisa melihat bahwa budaya asing begitu mudah memberikan pengaruh pada generasi muda seperti cara berpakaian bahkan cara bertingkah laku.

Merosotnya nilai-nilai Pancasila tersebut tentu menjadi keprihatinan bagi semua pihak baik pemerintah maupun masyarakat pada umumnya. Kita harus dapat mengembalikan nilai-nilai luhur Pancasila sebagai pandangan hidup masyarakat Indonesia. Oleh karena itu harus ada upaya untuk mengingatkan kembali dan menanamkan nilai-nilai Pancasila kepada masyarakat Indonesia.

Namun menanamkan nilai-nilai Pancasila bukanlah suatu hal yang mudah. Karena nilai-nilai tersebut harus melekat dan menjadi bagian dari hidup masyarakat Indonesia itu sendiri. Oleh karena itu nilainilai Pancasila perlu diperkenalkan sedini mungkin pada masyarakat Indonesia, yaitu pada masa anak-anak terutama sekolah dasar. Hal ini dikarenakan pendidikan di sekolah Dasar lebih cenderung mengutamakan aspek pembentukan mental dan moralitas. Selain itu pada masa ini anak masih berada pada tahap operasional konkrit menurut perkembangan kognitif Jean Piaget, dimana pada tahap ini anak cenderung untuk mulai menggunakan logika (http://paulineivy.blogspot.com).

Memperkenalkan nilai-nilai Pancasila pada anak-anak bukanlah suatu hal yang mudah karena rentang perhatian mereka masih sangat pendek. Oleh karena itu dibutuhkan suatu media yang dapat menstimulasi mereka agar dapat menerima nilai-nilai Pancasila dengan cara yang lebih mudah diterima. Salah satu media tersebut adalah film animasi 2D. Animasi yang merupakan terjemahan dari kata "animation" dalam kamus Umum Inggris-Indonesia berarti menghidupkan. Secara umum animasi merupakan suatu kegiatan menghidupkan, menggerakkan benda mati. Suatu benda mati diberikan dorongan kekuatan, semangat dan emosi untuk menjadi hidup dan bergerak, atau hanya berkesan hidup (Gatot Prakoso, 2010).

JJ Rousseau seorang tokoh pendidikan berpendangan bahwa seorang anak harus dididik sesuai dengan kemampuannya atau kesiapannya menerima pendidikan. Jadi, anak harus dipandang sesuai dengan alamnya dan jangan dipandang dari sudut orang dewasa saja (Suwarma dan Poedjiadi, 2012: 1.16). Senada dengan Suwarma dan Poedjiadi, Robert J. Havighurst mengemukakan bahwa setiap perkembangan individu harus sejalan dengan perkembangan aspek lain seperti di antaranya adalah aspek psikis, moral dan 
sosial. Dengan demikian dalam menanamkan nilai-nilai Pancasila pada anak-anak sekolah dasar diperlukan suatu media yang sesuai dengan tahap perkembangan mereka.

Film animasi dapat digunakan sebagai media menanamkan nilai-nilai Pancasila pada anak-anak sekolah dasar karena pada dasarnya di usia ini anak-anak cenderung lebih mudah untuk menangkap pendidikan yang menitik beratkan pada aspek visual. Selain itu pada usia 6-12 tahun anak-anak lebih cenderung suka meniru hal-hal yang dianggap menarik menurut mereka. Hal ini bisa kita lihat dari besarnya pengaruh film upin ipin, di benak anak-anak Indonesia. Apalagi saat ini masih sangat jarang film animasi di Indonesia, terutama yang bermuatan nilai-nilai Pancasila.

\section{KAJIAN REFERENSI}

\section{Penelitian tentang Pancasila}

Nilai-nilai Pancasila merupakan filsafat (pandangan hidup) bangsa Indonesia, sehingga menjadi jati diri bangsa yang diyakini sebagai sumber nilai atas kebenaran, kebaikan, keadilan dan kebijaksanaan dalam hidup bermasyarakat, berbangsa dan bernegara. Kaelan (2002: 47) mengatakan bahwa bangsa Indonesia sebagai kausa materialis dari Pancasila. Pandangan hidup dan filsafat hidup itu merupakan kristalisasi nilai-nilai yang diyakini kebenarannya oleh bangsa Indonesia yang menimbulkan tekad bagi dirinya untuk mewujudkannya dalam sikap tingkah laku dan perbuatannya.

Kualitas nilai-nilai Pancasila bersifat objektif dan subjektif. Nilai-nilai dasar Pancasila, yaitu ketuhanan, kemanusiaan, persatuan, kerakyatan, keadilan yang bersifat universal, objektif, artinya nilai-nilai tersebut dapat dipakai dan diakui oleh Negara-negara lain, walaupun tentunya tidak diberi nama Pancasila. Sebagai contoh, misalnya nilai kemanusiaan di Negara lain diberi nama atau dipahami sebagai humanisme, persatuan dipahami dengan istilah nasionalisme, kerakyatan dipahami dengan istilah demokrasi, keadilan dipahami dengan istilah kesejahteraan.

Kaelan mengatakan bahwa nilai-nilai Pancasila bersifat objektif dapat dijelaskan sebagai berikut (Purwastuti Andriani, 2002: 58-59):

1. Rumusan dari sila-sila Pancasila itu sebenarnya hakikat maknanya yang terdalam menunjukkan adanya sifat-sifat yang umum universal dan abstrak, karena pada dasarnya Pancasila adalah nilai.

2. Inti nilai-nilai Pancasila berlaku tidak terikat oleh ruang, artinya keberlakuannya sejak jaman dahulu, masa kini dan juga untuk masa yang akan datang untuk bangsa Indonesia dan boleh jadi untuk Negara lain 
yang secara eksplisit tampak dalam adatistiadat, kebudayaan dan tata hidup kenegaraan dan tata hidup beragama.

3. Pancasila yang terkandung dalam Pembukaan UUD 1945, menurut ilmu hukum memenuhi syarat sebagai pokok kaidah Negara yang fundamental, sehingga merupakan suatu sumber hukum positif di Indonesia. Oleh karena itu hierarkhi suatu tertib hukum di Indonesia berkedudukan sebagai tertib hukum yang tertinggi. Jika dihadapkan atau disejajarkan dengan ideologi-ideologi lainnya maka perbedaan yang mendasar adalah ideologi lain tersebut lahir dari pemikiran per orang atau hasil filsafat seseorang sedangkan Pancasila lahir sebagai refleksi filosofis bangsa Indonesia terhadap kehidupan sosio-kultural dan religious masyarakat Indonesia.

Nilai-nilai yang ada di Pancasila seharusnya tertanam pada seseorang sejak sudah bisa berinteraksi dengan dunia luar. Jika seseorang sudah bisa menanamkan nilai-nilai Pancasila itu maka seseorang akan bisa menjiwai dari Pancasila itu sendiri. Menurut Widjaja (1984: 4) mengatakan pancasila didalamnya mengandung nilai-nilai yang universal (bersifat umum) yang dikembangkan dan berkembang dalam pribadi manusia-manusia sesuai dengan kodratnya sebagai makhluk pribadi dan sebagai makhluk sosial.

Menurut Muhammad Syaifuddin dalam penelitiannya mengenai Pengamalan Nilainilai Pancasila dalam Masyarakat Desa Rumpuk Kecamatan Mantup Kabupaten Lamongan Berdasarkan Tingkat Kelulusan (2013), penanaman nilai-nilai Pancasila ini bisa membangkitkan kesadaran akan dirinyaatas tanggung jawab pribadi dan masyarakat. Salah satu tanggung jawab yang harus di laksanakan oleh masyarakat adalah sadar akan hukum yang berlaku saat ini. Karena dengan sadar akan hukum dapat menciptakan keseimbangan, keselarasan dan keserasian kehidupan masyarakat atas dasar kesadaran hukum yang berlaku. Kesadaran hukum masyarakat ini seharusnya ditujukan pada perwujudan dari nilai-nilai yang ada di Pancasila. Internalisasi nilai-nilai Pancasila ini sebenarnya adalah modal awal untuk menciptakan masyarakat yang sadar akan hukum yang berlaku.

Menurut Kaelan (2002: 248) realisasi dari internalisasi nilai-nilai Pancasila dapat diperoleh hasil sebagai berikut:

1. Pengetahuan, meliputi aktualisasi biasa, pengetahuan ilmiah dan pengetahuan filsafat. 
2. Kesadaran, selalu mengetahui pertumbuhan keadaan yang ada dalam diri sendiri.

3. Ketaatan yaitu selalu dalam keadaan sedia untuk memenuhi wajib lahir dan batin.

4. Kemampuan kehendak, yang cukup kuat sebagai pendorong untuk melakukan perbuatan

5. Watak dan hati nurani agar orang selalu mawas diri

Maka dari pernyataan Kaelan ini sesuai dengan apa yang menjadi tujuan dari Pancasila dimana internalisasi nilai-nilai Pancasila bisa membangun kesadaran hukum dan arahnya untuk bisa menaati peraturan hukum yang berlaku. Masyarakat saat ini dituntut harus mampu untuk bisa menginternalisasi nilainilai yang tekandung di Pancasila dalam kehidupan sehari-hari sebagai tumpuan dasar untuk hidup di negara yang berdasarkan pada hukum sehingga kongkretisitas dari menginternalisasikan nilai-nilai yang terkandung dalam Pancasila kepadamasyarakat adalah membangun kesadaran masyarakat akan hukum yang berlaku sehingga tercipta keselarasan hidup yang baik antara hukum dan masyarakat.

\section{Penelitian tentang Film Animasi}

Animasi merupakan suatu pergerakan gambar (atau tulisan) yang memiliki ciri-ciri dimensi waktu dan ruang, seperti tinggi, lebar, dalam dan pengaturan waktu (timming). Tujuan dari animasi adalah dengan memanipulasi gambar- gambar sedemikian rupa yang dimaksudkan untuk memberikan ilusi pada mata manusia agar melihat suatu pergerakan maka gambar yang bergerak atau hidup tersebut seolah-olah mempunyai nyawa, inilah yang disebut dengan animasi. Contoh dari animasi dapat dilihat pada film iklan dengan visualisasi animasi, film- film animasi pada layar lebar ataupun video compact disk (VCD), animasi Komputer, game, bahkan sampai pada pergerakan lampu yang berjalan yang terdapat pada papan papan reklame.

Kata animasi berasal dari bahasa latin 'anima' yang berarti jiwa (soul) atau nafas kehidupan. Animasi berawal dari semua penciptaan kehidupan, memberikan kehidupan ke dalam obyek yang tidak bernyawa (Harmen Hary, 1991: 3). Definisi tersebut mengartikan bahwa benda-benda mati dapat 'dihidupkan'.Pengertian tersebut hanyalah merupakan istilah yang memiripkan, dalam arti tidak harus diterjemahkan secara denotatif, melainkan simbol yang menyatakan unsur kedekatan. Animasi dipandang sebagai suatu hasil proses di mana obyek-obyek yang digambarkan atau divisualisasikan tampak hidup. Kehidupan tersebut dapat dinyatakan 
dari suatu proses pergerakan. Animasi lebih dekat dengan unsur gerak, suatu pergerakan yang menyatakan bahwa benda yang bergerak dapat dilihat sebagai sesuatu yang hidup. Kewajaran suatu istilah hidup dinyatakan dengan pergerakan. Hal ini dinyatakan karena kita selalu memandang sesuatu yang bergerak, tumbuh, berkembang adalah sesuatu obyek yang hidup. Dengan demikian animasi adalah suatu gambaran imaji yang tampak hidup karena adanya pergerakan itu sendiri.Secara mendasar pengertian dari (film) animasi adalah rangkaian imaji yang memvisualisasikan ilusi gambar bergerak dengan menampilkan gambar-gambar tunggal pada kamera film atau video dengan frame rate yang disesuaikan pada media komunikasinya dengan menampilkan adegan-adegan karakter sesuai dengan cerita dan tujuan pembuatan animasi.

Untuk pembahasan animasi sendiri masih dirasakan kurang populer sebagai bidang ilmu pengetahuan dibandingkan dengan ilmu-ilmu sosial maupun ilmu pasti. Ini dapat dilihat dari minimnya buku-buku yang mengulas secara mendalam tentang animasi. Sebagai bagian dari pengetahuan tentang seni, animasi cenderung memposisikan sebagai pengetahuan tentang seni menggambar, tentang ekspresi, di mana kemampuan terhadap hand drawing lebih diutamakan. Meskipun demikian buku-buku yang mengulas animasi terbitan luar negeri sudah cukup banyak memberikan pemahaman tentang kaidah-kaidah animasi yang saling melengkapi. Hanya saja pembahasan ini hanya memberikan tentang gambaran secara umum dan tidak dibahas pada suatu pemahaman yang mendalam tentang karakter yang meliputi aspek bentuk, proporsi, atribut, postural cues, facial cues, gestural, proxemic cues dan personalitya.

John Halas and Roger Manvell, mengulas secara umum tentang pemahaman karakter ditinjau secara proporsi, pengembangan ekspresi, bentuk serta proporsi, Banyak sekali contoh-contoh tentang karakter beserta pensifatannya dijelaskan dalam buku ini. Meskipun sedikit yang dijelaskan tentang proses pembentukan karakter, buku ini sangat berguna untuk memahami karakter ditinjau dari aspek bentuk. Dia menjelaskan untuk memahami sebuah karakter, maka harus ada ketetapan tentang type karakter, dengan demikian segala sesuatu yang berkaitan dengan bentuk, ekspresi dan kesan harus dapat mencerminkan tipe apa yang akan ditetapkan, apakah cenderung kasar, jahat, halus dan sebagainya (1971: 185).

Sementara Kit Laybourne, dalam buku The Animation Book, a Complete Guide to 
Animated Filmmaking From Flip Book to Sound Cartoons, 1971, banyak mengulas dan menjabarkan sejarah animasi, trik-trik untuk menganimasikan obyek, serta tata suara dan pencahayaan untuk animasi cell. Berbagai model (gambar) karakter juga ditunjukkan dengan gerak-gerak kunci untuk pose suatu adegan. Buku ini menjadi acuan dalam mengolah kreativitas animator untuk mengekspresikan suatu pose adegan yang tentunya berguna dalam penelitian ini.

Harmen Hary, seorang penulis buku panduan animasi cell, dengan judul Animasi (1991) menjelaskan tentang karakter animasi adalah sebagai subyek yang harus mendapatkan titik perhatian (focus) dalam pengadeganan. Dia juga mengulas antisipasi untuk ekspresi gerak karakter yang banyak mengambil contoh gerak dari Walt Disney.Beberapa buku di atas sangat menunjang dalam pembelajaran animasi, khususnya studi tentang karakter untuk lebih memperjelas adanya pemahaman tentang berbagai aspek tentang penciptaan karakter animasi.

\section{Studi Pendahuluan}

Dalam penelitian ini, peneliti telah melakukan studi pendahuluan untuk mendapatkan data awal sebagai bahan untuk perancangan film animasi 2D sebagai media menanamkan nilai-nilai Pancasila.Keberadaan animasi disadari memiliki daya tarik tersendiri sebagai suatu bentuk sarana komunikasi yang menghibur yang disajikan lewat film-film layar lebar, televisi hingga game-game saat ini. Seiring dengan perkembangan teknologi informasi, seni yang menggunakan gambar dan modeling sebagai media ekspresi ini mulai berkembang pesat di banyak Negara.Bahkan di beberapa Negara, film animasi telah dianggap sebagai karya seni dan industri film. Di Indonesia sendiri film animasi mulai diperkenalkan kepada masyarakat melalui film-film produksi Walt Disney, seperti serial Mickey Mouse, Donal Duck, Snow White and Seven Dwarfs, dan sebagainya.Selai itu juga popular film-film animasi produksi Hanna Barbera seperti Tom and Jerry, The Huckleberry Hound, Yogi the Bear danScooby Doo. Pada akhir-akhir ini banyak sekali ditayangkan film-animasi produksi Jepang yang dikenal dengan Anime.

Film animasi saat ini dapat dikatakan masih mempunyai banyak peminat terutama anak-anak dan remaja. Hal ini dapat dilihat dari porsi tayang untuk film animasi di televisi. Beberapa tahun yang lalu film animasi hanya bisa dilihat pada hari minggu, tapi saat ini kita dapat melihat tayangan film animasi hampir di semua hari dan semua stasiun televisi swasta di Indonesia. Setiap stasiun televisi banyak yang 
memutar film animasi sebagai program acara untuk menarik minat pemirsa pada stasiun televisi tersebut (citra rating). Film-film animasi yang ditayangkankan pun beragam, dari 2 Dimensi dan 3 Dimensi serta perpaduan keduanya. Akan tetapi kebanyakan film animasi yang popular adalah animasi 2 Dimensi buatan industri animasi jepang yang kita kenal dengan istilah Anime.

Berdasarkan pengamatan, sebagian besar film animasi yang tayang di televisi Indonesia adalah film-film animasi buatan luar seperti Upin Ipin, Bernard Bear, Shaun The Sheep, Naruto, dll. Masih sangat jarang film animasi buatan Indonesia yang tayang di televisi.

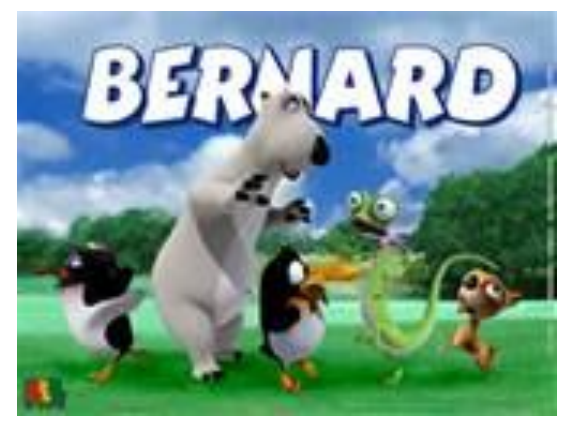

Gambar 1 Animasi Bernard the Bear Sumber: www.lordubay.wordpress.com

Namun karena film-film animasi tersebut dari luar Indonesia maka nilai- nilai yang terkandung di dalamnya pun tentu berbeda dengan nilai-nilai budaya bangsa Indonesia. Saat ini hanya ada beberapa film animasi Indonesia yang tayang di televisi. Dari sedikit film Animasi Indonesia yang saat ini sedang tayang di antaranya adalah Segah Nusantara dan sahabat.
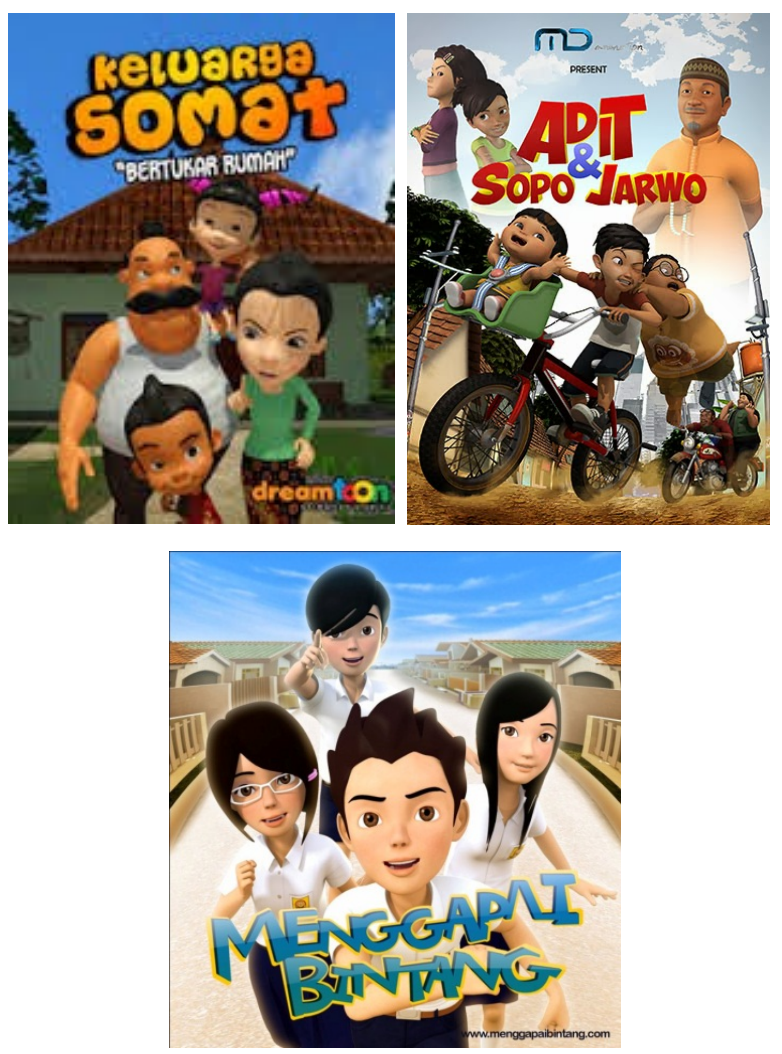

Gambar 2 Film animasi anak negeri Sumber: http://lintas.me.com

\section{METODE PERANCANGAN}

\section{Jenis Data}

Data dalam penelitian ini dibagi menjadi 2 (dua), yaitu:

\section{Data Verbal}

Data verbal adalah data yang berupa tulisan. Data verbal dapat diperoleh dari hasil telaah pustaka dari referensi-refernsi baik yang berupa dokumen, buku, jurnal, makalah dll yang memuat tentang apa yang akan dibahas dalam perancangan ini. 


\section{Data Visual}

Data visual merupakan data yang diperoleh dari hasil dokumentasi yang berupa foto, video, maupun gambar yang terkait dengan obyek dari perancangan tersebut.

\section{Metode Pengumpulan Data}

Dalam penelitian ini, data diperoleh melalui dua cara, yaitu:

1. Penelitian kepustakaan/Studi pustaka

Penelitian Kepustakaan merupakan metode pengumpulan data yang berupa studi dokumen yaitu mengumpulkan data yang berupa tulisan- tulisan, naskah-naskah baik itu berupa buku, jurnal maupun makalah.Data yang diperoleh dalam studi pustaka ini berupa data sekunder.

2. Penelitian lapangan (field research).

Dari penelitian lapangan akan diperoleh data primer yang merupakan hasil dari wawancara, obeservasi serta dokumentasi. Sumber dari data lapangan ini adalah orangorang yang dapat dimintai informasinya, atau informan termasuk key persons, yaitu orangorang yang karena lamanya berada di suatu tempat atau daerah, dipandang tahu benar seluk beluk keadaan tempat atau daerah itu. Field Research dalam penelitian ini dilakukan dengan cara wawancara serta observasi.

\section{Metode Analisis Data}

1. What, Penelitian dan perancangan ini adalah menghasilkan sebuah bentuk tayangan edukasi yang bersifat menghibur dan diharapkan ada suatu bentuk pemahaman yang dapat dilihat oleh khalayak sasaran. Informasi ini merupakan narasi cerita dalam bentuk film yang sekaligus mempunyai edukasi terhadap nilai-nilai Pancasila yang diambil dari peristiwa dan kejadian umum, agar dapat dengan mudah dipahami. Dalam hal ini nilai-nilai Pancasila yang direfleksikan dari cerita yang disampaikan memang tidak dapat mengakomodir semua nilai-nilai Pancasila, meskipun demikian dengan pertimbangan edukasi, maka nilai-nilai Pancasila yang disampaikan akan disesuaikan dengan kondisi psikologis dari sasaran khalayak yang diambil dari realitas kesehariannya, yakni di lingkungan rutinitasnya.

Adanya kondisi pertemanan yang terkadang tidak baik dan tidak sesuai dengan norma susila dan budaya Indonesia, memang menunjukkan adanya penyimpangan dari ajaran nilai-nilai Pancasila. Salah satu yang sering terjadi adalah dominasi dalam pertemanan, yang mengakibatkan situasi pertemanan yang tidak harmonis. Inilah yang kemudian menjadi dasar penciptaan narasi cerita sekaligus membatasi ruang lingkup alur 
cerita yang lebih banyak mengambil seting lokasi di rutinitas karakter dalam kesehariannya.

Sesuai dengan tema yang diambil adalah tentang dominasi atau kekerasan dalam pertemanan, maka edukasi yang akan disampaikan melalui narasi cerita adalah yang berkaitan dengan nilai-nilai persatuan dan kemanusiaan. Penanaman nilai-nilai Pancasila ini dipandang sangat signifikan sebagai bentuk implementasi tingkah laku dalam keseharian, sehingga diharapkan ada edukasi bahwa sebagai pribadi yang baik adalah menjaga dirinya untuk menjadi pribadi sosial, bahwa individu tidak dapat dilepaskan sebagai makhluk sosial, sehingga perlu menjaga tingkah laku dan perilakunya untuk saling menghargai, tolong menolong dan tidak menimbulkan kesenjangan dalam arti kekerasan ataupun dominasi fisik.

Adapun media yang digunakan untuk menyalurkan narasi cerita ini, tentu disesuaikan dengan situasi psikologis target audience, yakni anak-anak. Dengan demikian teknik penyajian dengan menggunakan animasi ditetapkan sebagai gambaran visualnya. Animasi 2D dipilih sebagai visualisasi dalam bentuk film, dengan pertimbangan bahwa teknik ini mempunyai teknik visual yang sederhana dan tidak serumit teknik 3D yang tentu memakan biaya dan waktu sangat tinggi. Disamping itu dengan visualisasi 2D, maka karakter yang dibuat menjadi lebih ekspresif visualisasinya dan mendekatkan imajinasi tontonan seperti halnya melihat buku bergambar atau komik, yang tentunya sangat dekat familiar di kalangan anak anak.

2. Who, Secara umum penerima informasi ini adalah anak-anak sekolah dasar, yang mempunyai rentang pendidikan dari kelas satu sampai dengan kelas 6 . Target audiens ini juga bersifat umum, dalam arti tidak dibatasi pada segmen sosial, gender, latar belakang agama serta budaya. Hal ini untuk menunjukkan bahwa edukasi tentang nilainilai Pancasila ini adalah bersifat general, dan tidak merujuk pada segmentasi tertentu. Pancasila adalah mutlak difahami oleh seluruh masyarakat Indonesia tanpa terkecuali.

Anak-anak sendiri ditetapkan sebagai sasaran khalayak film ini, didasarkan bahwa usia dini sebelum memasuki usia remaja dan dewasa perlu diberikan pemahaman yang benar sebagai pedoman mereka dalam berinteraksi, berkawan. bersosialisasi dan memandang sebuah pertemanan yang baik, yang kelak akan terus di jalani di kemudian hari. Dan dalam usia ini, pada dasarnya mereka akan mudah meniru, mengingat serta memahami sebuah gambaran visual, sehingga 
cerita animasi dengan penanaman nilai-nilai Pancasila ini menjadi sangat penting untuk diberikan.

3. Why, Sesuai dengan penjelasan pada aspek pertama (what), bahwa penanaman moral amatlah penting untuk dilakukan sejak usia dini. Disamping tugas pendidik menyampaikan ilmu pengetahuan sebagai bekal pendidikan, tentunya penanaman moral bisa bersumber dari segala aspek, baik lisan maupun non lisan. Film animasi 2D yang bertemakan penanaman nilai-nilai Pancasila ini adalah sebuah pelengkap yang diharapkan dapat diterima dan difahami, bagaimana sebenarnya konsep berteman yang sesuai dengan standar norma dan nilai-nilai Pancasila. Film ini tentu berbeda dengan bahasa ujar yang sering disampaikan oleh para orang tua dan pendidik terhadap anak-anak. Film ini ingin menunjukkan bagaimana sebuah visualisasi perilaku yang buruk dan baik untuk sebuah pertemanan. Dan dengan bentuk film animasi, maka nilai-nilai edukasi ini tentunya akan mudah sekali difahami karena disampaikan dengan sebuah cara bercerita visual, yang dapat diamati dan dicermati tanpa mereka-reka bagaimana sebenarnya norma-norma tersebut difahami melalu sebuah tayangan hiburan.
4. Where, Hasil perancangan ini memang tidak diperuntukkan untuk tayangan di media yang bersifat komersial, seperti di televisi ataupun layar lebar. Disamping keterbatasan pendanaan, tayangan ini pada dasarnya adalah dirancang untuk dipertontonkan di sekolahsekolah dasar dengan mengambil jam-jam ekstra kurikuler agar tidak mengganggu jam pelajaran serta dapat di tayangkan kapan pun juga sehingga lebih efektif dan dapat dilihat oleh seluruh siswa sekolah dasar tanpa harus mengeluarkan biaya.

5. When, Sesuai dengan karakteristik perancangan ini yang memang tidak diperuntukkan untuk media berbayar, seperti televisi dan layar lebar, maka film animasi 2D yang dikemas dalam format DVD ini dapat didistribusikan di sekolah-sekolah dasar dan ditayangkan dengan menyesuaikan jam-jam ekstra kurikuler atau mengambil momentmoment pada saat penerimaan siswa baru.

6. How, Perancangan film animasi 2D dengan tema cerita edukasi ini akan di hasilkan melalui tahapan tahapan secara umum seperti yang dilakukan dalam biro-biro production house, yakni tahap Pra produksi, yakni menghasilkan konsep yang akan divisualkan. Tahap Produksi yakni tahapan pengerjaan animasi 2D, dan tahapan Paska Produksi yang 
berisi editing film animasi meliputi pengisian suara, koreksi warna serta efek-efek visual yang bisa ditambahkan yang selanjutnya akan disebut sebagai master film yang disimpan dalam format DVD.

\section{Langkah-Langkah Perancangan}

Tahapan yang dilakukan dalam perancangan Film animasi $2 \mathrm{D}$ ini dibagi menjadi tiga tahap, yaitu tahap pra produksi, tahap produksi serta tahap pasca produksi. Tahap pra produksi meliputi:

1. Sinopsis (Outline)

2. Scenario (script)

3. Storyboard

4. Desain Karakter (Character Design)

5. Desain Background (Environment Design)

Setelah tahap pra produksi selesai kemudian dilakukan tahap produksi yang meliputi:

1. Pembuatan Background

2. Pembuatan Keypost

3. Pembuatan Inbetween

4. Proses Scanning

5. Proses Colouring

6. Proses Compossing

Setelah proses produksi selesai maka tahap selanjutnya adalah tahap pasca produksi yang meliputi proses dubbing dan editing.

\section{HASIL DAN PEMBAHASAN}

\section{Tujuan Komunikasi}

Perancangan komunikasi visual dengan media animasi ini pada dasarnya sebagai sarana penyampaian pesan tentang realitas pertemanan kepada sasaran khalayak, yakni anak-anak sekolah dasar. Adapun pesan yang ingin disampaikan adalah mengedukasi sasaran khalayak tentang niai nilai Pancasila sebagai budaya dasar masyarakat Indonesia, bahwa terdapat nilai-nilai positif yang seharusnya dijadikan pola dan sikap perilaku, terutama tentang kemanusiaan dan persatuan. Dengan demikian maka tujuan komunikasi yang ingin disampaikan adalah :

1. Mendapatkan pemahaman dalam berperilaku dan berteman, bahwa sesama teman hendaknya saling menghargai dan tidak saling menyakiti.

2. Mendapatkan pemahaman bahwa teman yang baik adalah yang tidak menunjukkan arogansi sehingga akan menjadikan rasa saling memusuhi.

3. Mendapatkan pemahaman bahwa kebaikan dalam pertemanan adalah yang utama.

4. Mendapatkan pemahaman bahwa menyakiti teman lain akan membawa dampak buruk dalam sikap dan tingkah laku, baik dalam lingkungan pertemanan maupun keluarga. 


\section{Strategi Komunikasi}

Readibilitas, Legibilitas serta Plot dan Story pesan adalah aspek utama dalam setrategi komunikasi, dengan demikian, sesuai dengan tujuan komunikasi dalam perancangan film animasi ini maka, setrategi komunikasi yang ditetapkan adalah menggunakan pendekatan:

1. Bahasa yang digunakan menggunakan Bahasa Indonesia yang mudah difahami oleh semua anak anak di Indonesia.

2. Menghindarkan kata-kata verbal dan bahasa visual yang tidak mendidik atau menunjukkan sadisme dan unsur Sara.

3. Untuk mempermudah pemahaman tentang plot cerita dalam pertemanan, maka mengambil seting di lingkungan sekolah dan keluarga

4. Untuk mempermudah pemahaman tentang story cerita, maka dikisahkan gambaran cerita yang sederhana, yang sering ditemukan dalam lingkungan sekolah dan keluarga.

5. Gambaran cerita film, menggunakan plot linier yang menggunakan pola drama 3 babak, yakni eksposisi, konflik dan katarsis.

6. Untuk mempermudah dalam memahami cerita yang disesuaikan dengan target audience, maka menggunakan konsep alur, sebagai gambaran tema cerita film.

\section{Tujuan Media}

\section{Reach}

Reach atau jangkauan media film mempunyai penetrasi komunikasi yang cukup tinggi, mengingat medium ini dapat pula ditayangkan di acara televisi ataupun di media interaktif seperti internet, khususnya di media media sosial, sehingga diharapkan dalam sekali tayang maka media ini dapat diakses oleh banyak audience di seluruh penjuru tanah air. Di sisi lain medium ini juga dapat digandakan dengan mudah dengan system digital ataupun dalam keping $\mathrm{vcd} / \mathrm{dvd}$ sehingga siapapun dapat memiliki informasi ini.

\section{Frequency}

Terpaan informasi ini memang sangat tergantung dengan operator media dan pengakses informasi.Namun demikian, medium film mempunyai sifat yang retrieval, dalam arti dapat ditayangkan berulang-ulang sehingga mempunyai nilai frekuensi informasi (exposure) yang tinggi.

\section{Continuity}

Film animasi ini dirancang sebagai edukasi untuk siswa sekolah dasar dalam rangka lebih menghayati nilai nilai pancasila. 
Tentu akan sangat sulit semua aspek dan nilainilai Pancasila didistribusikan ataupun dimanifestasikan dalam bentuk film, mengingat film animasi ini adalah film animasi pendek yang mengambil sebuah tema dasar tentang kekerasan dalam pertemanan. Mendasari bahwa film ini berfokus pada aspek pertemanan dan kekerasan (bullying), maka akan sangat terbuka dan memungkinkan pesan-pesan yang disampaikan lewat media film animasi ini dikemas dalam bentuk cerita yang mempunyai kontinuitas tema-tema dasar yang lain. Untuk pilot project ini, tema yang diambil adalah mengambil situasi sekolah terutama fenomena pertemanan siswa sekolah dasar.

\section{Strategi Media}

\section{Audience Profile}

- Anak anak tingkat sekolah dasar

- Berdomisili di segala wilayah Indonesia

- Segala segmen sosial

\section{Ruang Lingkup Media}

Sebagai sarana edukasi yang bersifat tontonan, maka film animasi menjadi salah satu alternative komunikasi yang sesuai dengan karakteristik anak-anak yang menyukai tayangan hiburan dalam bentuk animasi. Media ini mempunyai karakteristik yang fleksibel dalam arti dapat ditayangkan di beberapa media komunikasi digital, serta dapat digandakan dengan biaya yang relative murah. Film animasi ini terutama dapat ditayangkan di sela-sela jam ekstrakurikuler tingkat sekolah dasar, dan dimungkinkan untuk ditayangkan di media social, seperti youtube dan vimeo. Sebagai tambahan informasi dari keberadaan film animasi ini, maka media penunjang juga dirancang, diantaranya adalah:

- poster film

- packaging DVD

\section{Tujuan Kreatif}

Kreatifitas adalah aspek formal yang dapat membentuk gaya cerita maupun penyampaian pesan menjadi menarik serta tidak membosankan. Dan terutama adalah premis yang ingin disampaikan dapat diterima dan dipahami oleh sasaran khalayak.Dalam kaitan ini, maka tujuan kreatif dalam perancangan film animasi ini adalah:

1. Menghasilkan pemahaman dan dampak positif bagi sasaran khalayak, bahwa perbuatan yang merugikan teman lain adalah buruk bagi pertemanan, dan suatu saat akan terbalaskan.

2. Memberikan pemahaman dan gambaran positif bagi sasaran khalayak bahwa teman yang baik adalah saling menghargai dan tidak membeda-bedakan antara satu 
dengan yang lainnya, dalam arti yang lemah tidak untuk dikalahkan.

\section{Strategi Kreatif}

1) IsiPesan

Perancangan film animasi ini memberikan pesan yang bersifat humanism yang seharusnya dimiliki perilaku subyek sejak dini. Dengan memberikan edukasi untuk siswa sekolah dasar, maka isi pesan yang ingin disampaikan difokuskan pada:

a) Kekerasan dalam pertemanan adalah suatu bentuk bullying yang bertentangan dengan nilai-nilai Pancasila, khususnya nilai-nilai sila ke-2 dan sila ke-3.

b) Kekerasan dalam pertemanan membawa dampak psikologis pada anak.

c) Pertemanan yang baik adalah saling menghargai dan tidak memaksakan kehendak kepada lainnya.

d) Teman di sekolah adalah sahabat yang akan saling tolong menolong dalam kebaikan.

\section{2) Bentuk Pesan}

\section{Verbal Texts}

Pesan Verbal yang digunakan dalam film animasi ini menggunakan monolog dan dialog untuk menjelaskan suasana emosi serta interaksi subyek.Pesan verbal dalam film ini sekaligus menjadi alur cerita bagaimana memahami eksoposisi dari karakter dan alur cerita film. Kekuatan dalam cerita film terbentuk dari bentuk pesan verbal film yang akan mengkisahkan bagaimana awal kisah penceritaan yang akan dijadikan pemahaman psikologis dari karakter, serta adegan adegan cerita yang membentuk kisah cerita film.

\section{Visual Texts}

Pesan visual yang digunakan dalam perancangan film animasi ini menggambarkan adegan adegan visual yang disesuaikan dengan tema dasar film, yakni fenomena pertemanan.Dengan demikian setting visual yang divisualisasikan meliputi tempat-tempat di sekolah sebagai situasi umum interaksi siswa dengan siswa dan siswa dengan guru. Setting visual lain adalah mengambil tempat di rumah, sebagai gambaran psikologis antara siswa dengan keluarga.

Bentuk visual film ini, terutama mengilusterasikan adegan-adegan psikologis karakter serta adegan adegan yang melukiskan adanya kekerasan yang sering dijumpai di sekolah. Adapun teknik visual yang digunakan menggunakan sudut pandang yang mudah dipahami baik pose maupun adegannya, dengan menggunakan komposisi sudut 
pandang dekat dan sudut pandang jauh. Sudut pandang dekat digunakan untuk menggambarkan situasi psikologis karakter. Sedangkan sudut pandang jauh digunakan untuk memvisualisasikan situasi dan adeganadegan dari karakter serta interaksinya.

\section{Audio Texts}

Film animasi ini menggunakan background music yang disesuaikan dengan situasi psikologis tiap sequence dan scene-scene yang saling berhubungan. Musik yang digunakan untuk membentuk dan mempertegas situasi psikologis dari tiap sequence ini mengambil jenis music tanpa syair (instrumental) agar tidak mengurangi focus adegan adegan visualnya.

\section{3) Gaya Visual}

Untuk gaya visual film animasi ini menggunakan komposisi cut to cut dengan tempo yang disesuaikan dengan situasi psikologis adegan. Pendekatan komikal juga digunakan terutama untuk memperlihatkan kesan dramatikal serta kedalaman obyek materi dari visualisasi gambarnya yang cenderung flat style. Teknik pengambilan gambar yang digambarkan dalam visualisasi adegan film animasi ini juga bervariasi mulai dari angle dan pergerakan kameranya, agar supaya menjauhkan dari kesan monoton. Film animasi ini meskipun bersifat hiburan, akan tetapi gaya komunikasi yang digunakan bersifat dramatik yang ditambahkan penekanan suspense untuk beberapa adegan untuk menambah daya tarik visualnya.

\section{Pra Produksi}

Tahapan Pra-Produksi ini adalah tahap awal untuk merekonstruksi dan mematangkan bagaimana film animasi akan diproduksi. Tahap ini disebut juga dengan tahap konseptualisasi, hingga terbentuk naskah cerita film yang siap untuk divisualisasikan.

\section{1) Jenis Film}

Film animasi ini adalah berjenis film fiksi dengan genre drama. Film ini adalah film untuk anak-anak, sebagai hiburan yang juga dimasukkan unsur edukasi di dalamnya, terutama penanaman nilai-nilai Pancasila. Film animasi ini mengambil teknik visual animasi dua dimensi (2D) dengan durasi kurang lebih 15 menit.
a) Tema

Tema yang diambil dalam film animasi ini adalah "KEKERASAN

DALAM PERTEMANAN (BULLYING) 
b) Premis

Premis adalah makna yang akan disampaikan kepada sasaran khalayak. Premis merupakan gambaran umum dari makna yang bisa didapatkan dari penonton ketika melihat tayangan film. Premis dalam film animasi ini adalah: "SAHABAT SEJATI ADALAH SAHABAT YANG SALING TOLONG MENOLONG"

c) Seting

Seting lokasi dalam film ini mengambil lokasi di kota, yang terbagi menjadi 2 tempat, yakni di rumah sebuah keluarga, dan di sekolah dasar. Untuk seting keluarga, mengambil tempat interior rumah, sedangkan seting sekolah mengambil tempat di ruang kelas dan di luar kelas, serta di luar sekolah dasar. Seting tempat dan lokasi ini tetap mengilustrasikan ciri khas bangunan di Indonesia, akan tetapi tidak menunjukkan sebuah kota. Hal ini untuk memberikan petunjuk bahwa situasi cerita ini bisa terjadi di mana saja, sekaligus sebagai penyederhanaan alur cerita.

d) Sinopsis

\section{CERITA :}

Film animasi ini adalah film yang diperuntukkan untuk anak-anak tingkat sekolah dasar, yang mengambil tema tentang kekerasan dalam pertemanan. Adapun premis dari film drama ini adalah menyampaikan makna dari hubungan pertemanan bahwa sahabat sejati adalah sahabat yang saling tolong menolong dalam kebaikan dan tidak saling menyakiti. Film animasi ini pada dasarnya adalah gambaran dari manifestasi nilai-nilai Pancasila yang menggambarkan implementasi dari nilai-nilai kemanusiaan dan persatuan.

Awal kisah dari film animasi ini adalah sebuah flash-back dari kejadian yang dialami oleh ALDI, seorang anak sekolah dasar kelas 6, di sebuah sekolah dasar perkotaan pada umumnya. Dalam kejadian ini, ALDI telah mengalami kekerasan oleh teman satu kelasnya. Dia dipaksa dan diperalat oleh EKO untuk selalu memberikan jawaban ketika ulangan harian berlangsung. ALDI memang anak yang pintar di kelasnya, semantara EKO yang bertubuh sedikit lebih besar dan gemuk ketimbang ALDI cenderung malas belajar dan suka menjahili teman teman yang lain.

Kejadian tersebut telah membawa dampak psikologis terhadap ALDI. Dia menjadi enggan untuk sekolah dan nilai-nilai ulangan hariannya menjadi turun.ALDI menjadi pemurung dan pendiam. ALDI lebih suka menyendiri dan mengurung dalam kamar ketika di rumah. Hal ini tentu 
mendapat perhatian dari guru dan orang tua ALDI sendiri.

Cerita film kemudian menjadi meningkat, ketika orang tua ALDI dipanggil oleh guru wali kelasnya untuk datang ke sekolah.Konflik dalam cerita ini adalah ketika EKO dan teman-temannya mengalami kejadian kekerasan oleh anak-anak muda yang kebetulan mangkal di sekitar sekolah dasar tersebut. EKO dan teman-temannya justru mengalami kekerasan oleh orang lain ketika dia dan teman-temannya sering menjahili teman sebayanya. EKO justru ditinggalkan oleh teman-temannya yang ketakutan.

Anti klimaks dari cerita film ini digambarkan, ketika ALDI mengetahui peristiwa itu, dia datang menolong dengan seorang SATPAM sebuah Bank yang dipanggilnya. EKO menjadi sadar bahwa teman yang selama ini dijahili malah datang menolong.EKO sadar bahwa sahabat adalah teman yang saling menolong dalam kebaikan. Mulai saat itulah EKO menjadikan ALDI sebagai sahabat terbaiknya....dan dia tidak lagi menjahili teman-teman yang lain.

\section{e) Storyline}

\section{FILM ANIMASI 2D "BULLYING"}

SINAR BULAN MENEMBUS KACA JENDELA KAMAR. TAMPAK ALDI SEDANG TIDUR DI KAMAR YANG HANYA DITERANGI CAHAYA BULAN. WAJAHNYA AGAK BERKERINGAT DAN
SESEKALI BERGUMAM. TIDURNYA TAMPAK TIDAK NYENYAK, WAJAHNYA BERGERAK GERAK, SEMENTARA JAM MENUNJUKKAN PUKUL 3 MALAM. DI JENDELA TERLIHAT ANGIN BERTIUP KENCANG, MEMBUAT DAUN POHON BERGERAK GERAK LAKSANA MENARI DAN SESEKALI MENGENAI KACA JENDELA.

TIBA TIBA ALDI TERSENTAK BANGUN, DENGAN NAFAS YANG TERENGAH ENGAH.....INGATANYA KEMBALI KEPADA PERSTIWA SIANG TADI.

INGATANNYA TERTUJU PADA PERISTIWA KETIKA JAM ISTIRAHAT SEUSAI ULANGAN HARIAN MATEMATIKA. SAAT ITU IA TERJATUH PADA SAAT IA BERJALAN MELEWATI BANGKU YANG DIDUDUKI EKO. RUPANYA KAKI EKO SENGAJA MENGGANJAL KAKINYA SEHINGGA IA TERJATUH.....BEBERAPA TEMAN EKO MENERTWAKANNYA.

INGATANNYA KEMUDIAN KEMBALI PADA SAAT ULANGAN MATEMATIKA KETIKA EKO BERISIK DAN SELALU MENGGANGGUNYA UNTUK MENDAPATKAN JAWABAN DARI DIRINYA. IA MEMANG TAKUT DENGAN EKO YANG BERPERAWAKAN TINGGI BESAR TAPI MALAS BELAJAR. TETAPI IA JUGA TAKUT UNTUK MEMBERIKAN JAWABAN KEPADA EKO KARENA BU TYAS, GURUNYA SELALU MENEGUR DIRINYA DAN EKO UNTUK KONSENTRASI MENGERJAKAN JAWABAN SOAL MATEMATIKA.

IA SANGAT KESAL DAN MALU KETIKA MELIHAT WAJAH EKO DAN TEMAN-TEMANNYA MENYERINGAI, DAN MENERTAWAINYA KETIKA DIA JATUH DAN KACAMATANYA TERLEMPAR, SEHINGGA DIA AGAK KESULITAN MENGAMBIL BEBERAPA PENSIL YANG TERGULIR DIBAWAH MEJA.

IA MENCOBA UNTUK TIDUR KEMBALI, MEREBAHKAN TUBUHNYA SAMBIL MENARIK SELIMUTNYA...

IA TERSENTAK KAGET KETIKA JAM WEKKER BERBUNYI KERAS MENUNJUKKAN JAM 5 PAGI. BERBEGAS DIA TURUN DARI TEMPAT TIDUR. SAMAR SAMAR TERDENGAR SUARA KESIBUKAN DI DAPUR. TERDENGAR SUARA IBUNYA YANG MEMANGGIL MANGGIL NAMANYA UNTUK SEGERA MANDI DAN SHOLAT SHUBUH.

DENGAN LANGKAH GONTAI ALDI BERJALAN MEMASUKI GERBANG SEKOLAH DAN MENUJU RUANG KELAS V. TERLIHAT EKO BERDIRI DI SAMPING PINTU KELAS 
DIBARENGI BEBERAPA TEMANNYA ALDI MENUNDUKKAN KEPALANYA SAAT EKO MELIHAT WAJAHNYA. DENGAN PERASAAN BERDEGUP IA MELINTASI EKO, MENGHARAP TIDAK ADA KEJADIAN APA APA.

TIBA TIBA IA TERSENTAK KAGET KETIKA TAS RANSEL ADA YANG MENARIK. DIA MELIHAT EKO MEMEGANG TAS RANSELNYA SAMBIL BERKATA "MAU KEMANA KAU PROFESOR".....AWAS KALAU KAMU TIDAK MEMBERIKAN JAWABAN SOAL ULANGAN KALI INI" DENGAN PERASAAN TAKUT ALDI HANYA DIAM DAN MELANGKAHKAN KAKI MENUJU BANGKUNYA.

ALDI MENGERJAKAN SOAL ULANGAN DENGAN CEPAT, BERHARAP EKO TIDAK MENGGANGGUNYA. BU TYAS MEMPERHATIKAN ALDI...."KOK CEPAT SEKALI KAMU ALDI MENGERJAKAN ULANGAN HARI INI".....TANYA BU TYAS......"ANU BU....SAYA PUSING, SAYA MOHON IJIN PULANG"

HARI BERGANTI HARI.......DI SEKOLAH ALDI SERING DUDUK MURUNG DI HALAMAN KETIKA ISTIRAHAT, MESKIPUN BANYAK TEMAN TEMANNYA YANG MENGAJAKNYA BERMAIN, ALDI HANYA SESEKALI IKUT BERMAIN. SELEBIHNYA ALDI LEBIH BANYAK MEMBACA KOMIK NARUTO KESUKAANNYA. SEMENTARA EKO DAN TEMAN TEMANNYA BERMAIN BOLA DAN TERKADANG SEENAKNYA MENYURUH ANAK LAIN UNTUK MEMUNGUT BOLA.

HARI INI ALDI MERASA MALAS KE SEKOLAH. MESKIPUN IBU DAN AYAHNYA SUDAH MENYURUHNYA BANGUN DAN BERANGKAT SEKOLAH, ALDI MEMILIH UNTUK BERDIAM DI KAMARNYA. DIA BERKILAH TIDAK ENAK BADAN KEPADA AYAH DAN IBUNYA. PANDANGAN ALDI MENERAWANG JAUH KE JENDELA.......SUARA SUARA TERTAWA EKO DAN TEMAN-TEMANNYA YANG MENGEJEKNYA SELALU TERNGIANG DI TELINGANYA.

TIBA-TIBA PINTU KAMARNYA TERBUKA, IBUNYA MASUK DAN DUDUK DI SAMPING RANJANG ALDI. "IBU BARU SAJA MENDAPAT TELEPON DARI BU TYAS, IBU DISURUH MENGHADAP BELIAU, APAKAH ALDI TAHU ADA APA SEBENARNYA".........ALDI HANYA MEMALINGKAN MUKA. "BAIKLAH IBU AKAN KE SEKOLAH, ALDI SARAPAN SAJA, IBU SUDAH SIAPKAN DI MEJA MAKAN" SEGERA IBU ALDI MENUTUP PINTU KAMAR.
PANDANGAN ALDI MENATAP KOSONG KE ARAH TAS SEKOLAH YANG TERGELETAK DI MEJA BELAJARNYA....PANDANGANNYA MENERAWANG. HARI ITU ALDI SANGAT BAHAGIA, IBU DAN AYAH MEMBERIKAN KEJUTAN KEPADANYA. ALDI MENDAPAT TAS BARU DAN SEPATU BARU. "INI HADIAH UNTUK ALDI YANG SELALU BERPRESTASI DAN MENDAPAT NILAI TERTINGGI DI KELAS" KATA IBU ALDI. "YEEEEEE, MAKASIH IBU AYAH, WUIIII......”TERIAK ALDI.

"IBU ANI....PUTRA IBU, ALDI AKHIR AKHIR INI SANGAT BERBEDA, DIA TAMPAK SELALU MURUNG DAN JARANG BERGAUL DENGAN TEMAN-TEMANNYA. DAN YANG LEBIH ANEH LAGI BU, PR YANG KAMI BERIKAN JARANG DIKERJAKAN. HASIL ULANGAN HARIANNYA NILAINYA RENDAH DIBANDINGKAN DULU".......APAKAH ALDI SAKIT BU ANI?" "KALAU DI RUMAH MEMANG SEKARANG MENJADI PENDIAM DAN MENGURUNG DI KAMAR, KAMI PIKIR ALDI MENGERJAKAN PR, KARENA SETIAP KAMI TANYA ALDI SELALU MENJAWAB SEDANG MENGERJAKAN PR. BIARLAH NANTI AKAN SAYA TANYAKAN KEPADA ALDI, BU TYAS” KATA IBU ANI.

PAGI INI GERIMIS.....PINTU KAMAR ALDI TERBUKA, IBUNYA MASUK, "ALDI AYO BANGUN NAK, KE SEKOLAH"......."ALDI GA MAU SEKOLAH" JAWAB ALDI. "ALDI....AYO NAK, AYAH AKAN MENGANTARMU KE SEKOLAH" TIBA TIBA AYAHNYA JUGA SUDAH ADA DISAMPINGNYA. ALDI HANYA MEMANDANG JENDELA YANG TERLIHAT GERIMIS HUJAN.

“ALDI.....SEKOLAH ITU PENTING UNTUK MENIMBA ILMU DAN MASA DEPAN".....AYAH ALDI SUDAH DUDUK DISAMPINGNYA. “ALDI CERITAKAN SEBENARNYA ADA APA DI SEKOLAH, IBU SUDAH TAHU SEMUANYA, TENTANG KEBIASAANMU DI SEKOLAH DAN NILAI ULANGAN ALDI YANG TURUN, IBU TYAS MENCERITAKAN SEMUANYA PADA IBU"....

“ALDI TAKUT KE SEKOLAH" SAHUT ALDI. "ALDI TAKUT DENGAN EKO" SUARA ALDI MULAI BERGETAR, MENAHAN TANGIS. "KAMU DI APAKAN DENGAN EKO, NAK" TANYA AYAH ALDI. "POKOKNYA ALDI TAKUT DAN GA MAU SEKOLAH"......SUARA ALDI MENJADI LIRIH.

TELEPON GENGGAM BU TYAS BERDERING. "HALLO SELAMAT SIANG, DENGAN SIAPA INI....OH BU ANI, BAGAIMANA BU?" TERLIHAT BU TYAS MENGOBROL MENGOBROL DENGAN BU ANI. 
TERLIHAT EKO DUDUK DI RUANGAN KEPALA SEKOLAH. EKO SEDANG DINASEHATI OLEH BAPAK EDI, KEPALA SEKOLAHNYA. "AH SANTAI AJA” SAHUT EKO, KETIKA TEMANNYA MENANYAKAN PERIHAL DIA DIPANGGIL KEPALA SEKOLAH.

BEL TANDA PELAJARAN USAI BERBUNYI. EKO BERJALAN PULANG DITEMANI DUA TEMANNYA.....SEMENTARA ALDI BERJALAN PELAN DIBELAKANGNYA. KEPALANYA DITUNDUKKAN. AGAK JAUH DARI GERBANG SEKOLAH TERLIHAT 3 REMAJA SEDANG DUDUK DUDUK DI SAMPING PARIT. "HAI GENDUT SINI KAU" SALAH SEORANG REMAJA TADI MEMANGGIL EKO. SEMENTARA ALDI MENGHENTIKAN LANGKAHNYA DAN MELIHAT KEJADIAN DI DEPANNYA. DENGAN KASAR SALAH SEORANG REMAJA ITU MENARIK BAJU TAS RANSEL EKO. DUA TEMAN EKO LARI MENJAUH. SEMENTARA EKO SUDAH DIKELILINGI 3 REMAJA TADI.

"KALAU GENDUT GINI, PASTI DUITNYA BANYAK. TAPI OTAKNYA TUMPUL, KARENA PIKIRANNYA CUMA MAKANAN DOANG" KATA SALAH SEORANG REMAJA ITU, DAN DISAMBUT GELAK TAWA TEMAN-TEMANNYA. "SINI....UANGMU" SERGAH SALAH SATU REMAJA. TAS RANSEL EKO JATUH DAN KERTAS ULANGAN HARIANNYA IKUT KELUAR. "APA INI, BADAN AJA GENDUT TAPI ULANGANNYA KURUS, CUMA DAPAT 5, HAHAHAHAHA" KEMBALI 3 REMAJA TADI TERTAWA. EKO HANYA DAPAT TERDIAM, GEMETAR......."MANA UANGMU, NDUT"....."MAAF MAS, SUDAH TIDAK ADA, SUDAH HABIS BUAT JAJAN TADI"....."BOHONG, MANA DOMPETMU"......."BENER MAS SUSUSSUDAH HABIS MASSS"

TIBA TIBA KRAH BAJU EKO DITARIK. KEPALA KE DUANYA HAMPIR SAJA BERADU. "HMMM, KAMU JANGAN BOHONG YA” REMAJA INI TAMPAK MARAH SEKALI. SALAH SEORANG REMAJA INI TAMPAK MEMBUKA DOMPET EKO......"HUHHHH KOSONG" SUARA SALAH SATU REMAJA YANG MEMEGANG DOMPET EKO. DIBUANGNYA DOMPET EKO KE PARIT. EKO MENUNDUKKAN KEPALA, DAN DARI SUDUT MATANYA DIA MELIHAT ALDI YANG BERDIRI MELIHAT DARI BALIK POHON. TIBA TIBA 3 REMAJA INI TERTAWA TERGELAK........"LIHAT ....SI GENDUT INI KENCING...HAHAHAHAHAHA"

EKO SEMAKIN TAKUT, DAN TAK TERASA CELANANYA SUDAH BASAH. EKO SUDAH MULAI TERISAK ISAK. EKO MELIHAT ALDI BERLARI KE SEBERANG JALAN. DIA HANYA BISA MENANGIS DI KERUMUNI 3 REMAJA INI.
"HAI.....BUBAR....BUBAR....BUBAR" TIBA TIBA SUARA SEORANG LAKI-LAKI YANG MENDEKATI KERUMUNAN 3 REMAJA INI. SEORANG SATPAM MEMBENTAK DENGAN KERAS. DISAMPINGNYA ALDI JUGA IKUT MENDEKATI. KONTAN REMAJA REMAJA TADI LARI TUNGGANG LANGGANG KE UJUNG JALAN. EKO HANYA DAPAT TERDUDUK MALU KETIKA ALDI MENDEKATI BERSAMA SATPAM BANK YANG TAK JAUH DARI KEJADIAN INI. "INI DOMPETMU" ALDI MENGULURKAN DOMPET EKO YANG DIAMBILNYA DARI PARIT. EKO HANYA DAPAT MENGGUMAN “MAKASIH”

"UNTUNG TEMANMU INI MEMANGGIL SAYA, MEMANG KETERLALUAN ANAK-ANAK TADI" KATA BAPAK SATPAM. “KAMU TIDAK APA APA KAN" TANYA SATPAM......"I IIYA PAK.....GA PAPA" SAHUT EKO LIRIH. SEMENTARA ALDI MEMANDANGINYA. EKO HANYA TERTUNDUK, BADANNYA MASIH GEMETARAN MENAHAN TAKUT. “TERIMAKASIH ALDI” GUMAN EKO.

HARI INI ALDI TAMPAK SERIUS MENYIMAK PELAJARAN YANG DISAMPAIKAN BU TYAS. DIA MELIRIK EKO YANG TAMPAK MENCATAT APA YANG DISAMPAIKAN OLEH BU TYAS.

"BAIK ANAK-ANAK, IBU SANGAT SENANG.....ULANGAN PKN KEMAREN HASILNYA BAGUS BAGUS. IBU BENARBENAR SANGAT SENANG" KATA BU TYAS DISAMBUT TEPUK TANGAN MURID DI KELAS. BEL TANDA PELAJARAN USAI BERDERING. TAMPAK ALDI BERJALAN BER IRINGAN DENGAN EKO, DAN EKO MERANGKUL ALDI. DI BALIK KACA JENDELA, BU TYAS MEMANDANGINYA DENGAN SENYUMAN.

\section{----- SELESA I ------}

\section{f) Profil Karakter}

Beberapa karakter yang divisualisasikan adalah rekaan fiktif belaka dan tidak merujuk pada karakter siapa pun.

\section{ALDI}

Adalah karakter yang digambarkan sebagai seorang anak pandai di kelas dan menjadi 
tokoh utama dalam film. ALDI mempunyai tubuh agak kurus dan tinggi badan rata rata untuk anakusia sekolah dasar kelas $6(153 \mathrm{~cm})$. ALDI mempunyai rambut lurus dan dengan kebiasaan membaca yang tidak baik membuat dia akhirnya memakai kacamata minus. Sifat dan perangai ALDI pada dasarnya adalah periang, supel dan mudah bergaul dengan siapa saja, akan tetapi semenjak dia sering mendapatkan perlakuantidak baik dari temannya, EKO, maka ALDI digambarkan pula menjadi pendiam, pemurung dan suka menyendiri. ALDI adalah anak pertama dari keluarga SUSILO (Bapak SUSILO dan Ibu ANI), Sebuah keluarga sederhana, di mana ALDI sendiri selalu berangkat sekolah dengan berjalan kaki. Rumah ALDI memang tidak jauh dari sekolah tempat dia menimba ilmu.

\section{$\mathrm{EKO}$}

Adalah karakter yang digambarkan sebagai anak yang kurang rajin belajar di sekolah.EKO mempunyai bentuk tubuh gemuk dan lebih tinggi daripada ALDI, yakni sekitar $158 \mathrm{~cm}$, dan berkulit agak gelap (sawo matang). Dengan badan yang relative besar dari teman sebayanya, dia sering menjahili teman-teman yang lain. EKO sendiri memang mempunyai kebiasaan usil. Akibatnya dia kurang disukai teman-temannya dan sering ditegur guru di kelas karena kurang memperhatikan pelajaran.

\section{$\mathrm{Bu} \mathrm{ANI}$}

Adalah karakter yang digambarkan sebagai ibu dari ALDI. Bu ALDI adalah karakter dengan sifat penyabar dan penyayang. Mempunyai bentuk tubuh langsing, seperti kebanyakan ibu ibu muda, berambut lurus sebahu, mempunyai kulit kuning langsat dan berparas cantik. Usia Ibu ANI kurang lebih 35 tahun.

\section{Bapak SUSILO}

Adalah karakter yang digambarkan sebagai ayah dari ALDI, seorang pegawai kantor pemerintah. Bapak SUSILO mempunyai bentuk tubuh yang agak gemuk dan usianya tidak terpaut jauh dengan Bu ALDI, yakni sekitar 37 tahun. Berambut lurus dan berkulit agak kecoklatan. Sifat Bapak SUSILO sendiri tidak jaug berbeda dengan Ibu ANI yang penyabar dan penyayang, hanya saja ayah ALDI ini memang cenderung pendiam.

\section{SATPAM}

Digambarkan sebagai karakter pelengkap dalam cerita, yang menolong EKO ketika mendapat perlakuan kasar dari beberapa remaja. SATPAM ini adalah security Bank BNI yang terdapat di samping sekolah dasar 
tempat EKO dan ALDI bersekolah. Karakter SATPAM digambarkan bertubuh tegap dengan baju lengkap security Bank.

\section{Bu TYAS (Ibu Guru Wali Kelas 6)}

Karakter guru ini digambarkan sebagai guru wanita muslim yang menggunakan jilbab. $\mathrm{Bu}$ TYAS digambarkan sebagai karakter guru yang mempunyai tubuh langsing, dengan tinggi sekitar $160 \mathrm{~cm}$ dan menggunakan kacamata baca.Umur Bu TYAS kurang lebih 45 tahun.

\section{g) Study Visual}
a. Identifikasi

Untuk memperdalam penciptaan karakter dalam cerita animasi ini diperlukan studi visual beberapa karakter yang dimunculkan yang dapat diterima sebagai sebuah penggambaran figuratif dari peranperan yang dimunculkan, baik profil dan tipologinya. Studi visual ini adalah penggambaran figuratif dari realitas manusia dan lingkungannya yang kemudian dikembangkan secara deformatif yang menyesuaikan dengan karakter animasi 2D tanpa menghilangkan kesan karakter yang sebenarnya.
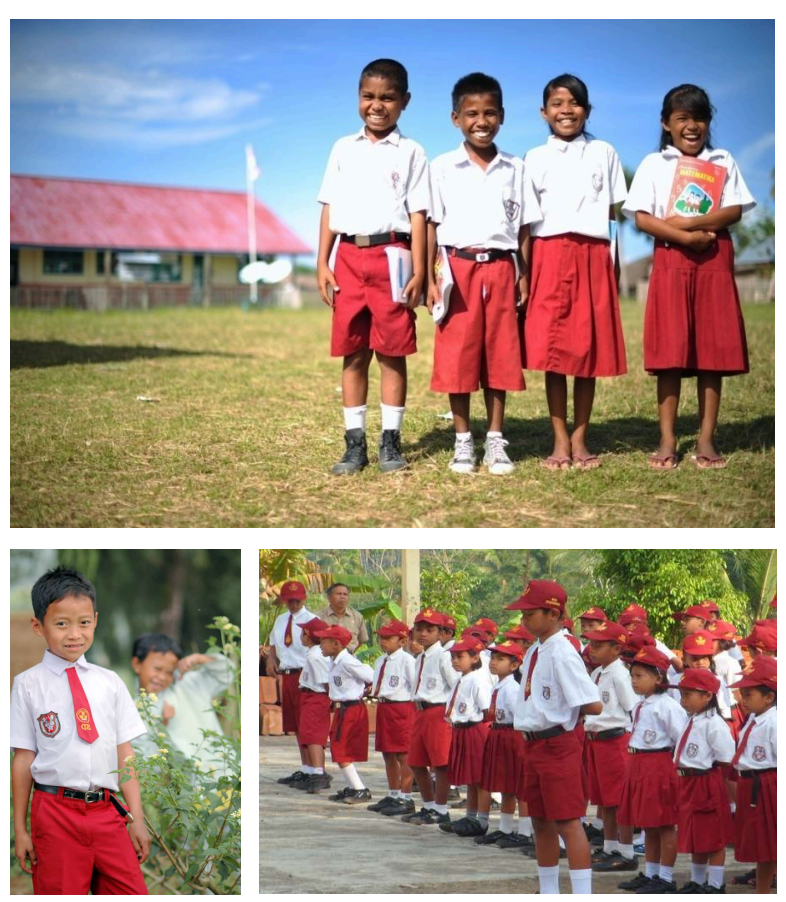

Gambar 3 Figur Anak-Anak SD Sumber:

http://ayomengajarindonesia.blogspot.co.id/2013/01/ cara-mengajar-anak-sekolah-dasar.html

Studi visual adalah sebagai fakta realis atau pedoman awal bagaimana keberadaan penciptaan karakterisasi dalam cerita animasi ini akan divisualisasikan. Selanjutnya dibuat sketsa karakterisasi sesuai dengan penggayaan (model) animasi 2D.

b. Desain Karakter

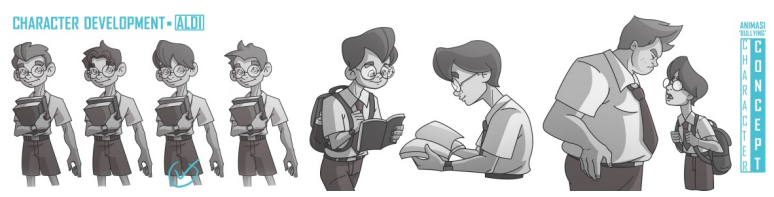


h) Story Board

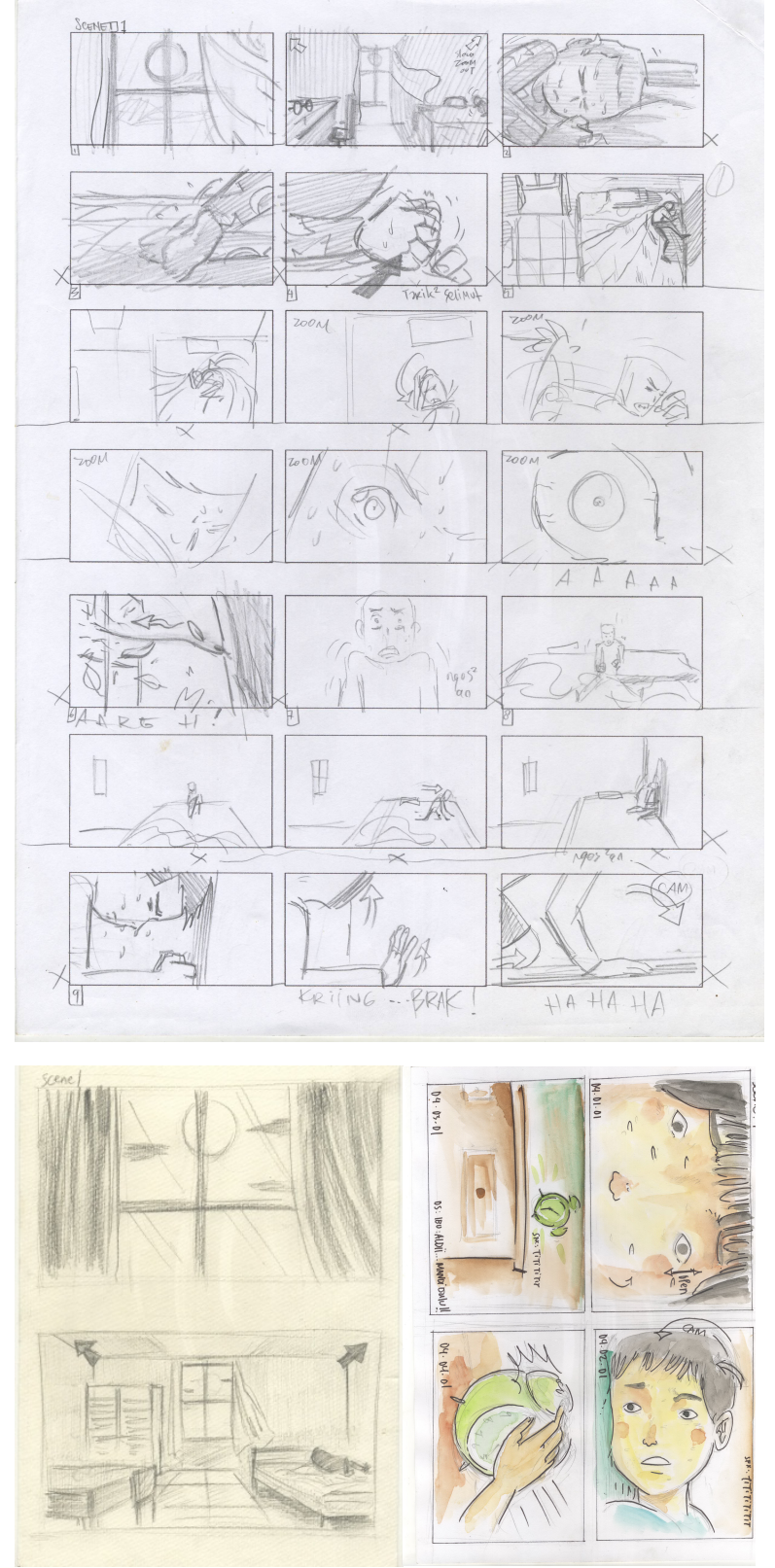

\section{KESIMPULAN}

Film animasi dapat digunakan sebagai media menanamkan nilai-nilai Pancasila pada anak-anak sekolah dasar karena pada dasarnya di usia ini anak- anak cenderung lebih mudah untuk menangkap pendidikan yang menitik beratkan pada aspek visual. Selain itu pada usia 6-12 tahun anak-anak lebih cenderung suka meniru hal-hal yang dianggap menarik menurut mereka. Hal ini bisa kita lihat dari besarnya pengaruh film upin ipin, di benak anak-anak Indonesia.Apalagi saat ini masih sangat jarang film animasi di Indonesia, terutama yang bermuatan nilai-nilai Pancasila, bahkan tak jarang film-film animasi justru bertentangan dengan nilai-nilai Pancasila.

Film animasi 2D dengan judul "Bullying" ini merupakan sebuah film animasi yang mengajarkan anak-anak sekolah dasar tentang nilai-nilai Pancasila dengan media yang sesuai dengan usia mereka. Film ini dibuat dengan format DVD, berdurasi 15 menit dan kurang lebih 210 scene. Dengan banyaknya scene dalam film ini maka proses perancangannya memerlukan waktu dan biaya yang tidak sedikit terutama dalam proses pembuatan film animasinya yang memerlukan hasil gambar dalam hitungan 24 frame per detik. Kendati film ini merupakan film animasi pendek, akan tetapi diharapkan dengan plot serta penceritaan yang sederhana dan mudah untuk dipahami, diharapkan anak-anak dapat memahami bagaimana tema film animasi ini disampaikan, terutama tentang penanaman nilai-nilai Pancasila yang berkaitan dengan sila persatuan.

\section{REFERENSI}

[1] Gatot Prakoso, 2010, Animasi Pengetahuan Dasar Film Animasi 
Indonesia, Jakarta: FFT-IKJ dengan Yayasan Seni Visual Indonesia.

[2] Harmen Hary, 1991, Animasi, Yogyakarta: Multi Media Training Center

[3] Iwan Nugroho, 2013, Nilai-nilai Pancasila Sebagai Falsafah pandangan Hidup Bangsa Untuk Peningkatan Kualitas sumber Daya Manusia dan Pembangunan Lingkungan Hidup. Jurnal Puskasi Universitas Widyagama Malang, volume 3 (2) hal 107-127.

[4] Halas, Johan and Manvell, Roger, 1971, The Technique of Film Animation, London and New York: Focal Press.

[5] Kaelan. 2002. Filsafat Pancasila Pandangan hidup Bangsa Indonesia. Yogyakarta : Paradigma

[6] Kaelan. 1996. Filsafat Pancasila. Yogyakarta: Paradigma

[7] Kaelan, 2004, Pendidikan Pancasila, Yogyakarta: Paradigma.

[8] Laybourne, Kit, 1981, The Animation Book, a complete guide to animated filmmaking from flip books to sound cartoons, New York: Crown Publisher, Inc.

[9] Ms Bakry, Noor. 1994. Pancasila Yuridis Kenegaraan. Yogyakarta: Liberty.

[10] Syaifuddin, Muhammad, 2013, Pengamalan Nilai-niali Pancasila Dalam Masyarakat Desa Rumpuk Kecamatan Mantup Kabupaten Lamongan Berdasarkan Tingkat Kelulusan.

[11] Notonagoro, 1997, Pancasila Secara Ilmiah Populer, Jakarta: Bumi Aksara.

[12] Purwastuti, Andriani, dkk, 2002 Pendidikan Pancasila, Buku Pegangan Kuliah, Yogyakarta: Unit Pelaksana Teknis Universitas Negeri Yogyakarta.

[13] Widjaja, Drs. 1984, Kesadaran Hukum Manusia dan Masyarakat Pancasila, Jakarta: CV Era Swasta.

\section{Tautan}

[1] http://paulineivy.blogspot.com, Teori perkembangan Kognitif Jean Piaget dan Implementasinya 